\title{
An insight into Old Hittite metallurgy: alloying practices at Hüseyindede (Çorum, Turkey)
}

\author{
Gonca Dardeniz, ${ }^{1}$ İ. Tunç Sipahi ${ }^{2}$ and Tayfun Yıldırım² \\ ${ }^{1}$ Koç University, Turkey, and ${ }^{2}$ Ankara University, Turkey \\ gdardeniz@ku.edu.tr
}

\begin{abstract}
This paper presents archaeological and analytical data on metal artefacts from Hüseyindede (Çorum, Turkey), dated to the Old Hittite period (ca 16th century BC). Hüseyindede, which is set in a rural landscape, demonstrates continuity in alloying traditions from the Early Bronze Age III (ca 26th/25th-22nd/21 st century BC) and the Assyrian Trading Colonies period (20th-18th century BC) to the emergence of the Hittites. In addition to known alloying practices of the period, the site presents, for the first time, evidence of the existence of copper-nickel alloys, namely cupronickels, which so far have been documented only at the Late Bronze Age capital of the Hittites, Boğazköy/Hattuša. The Hüseyindede cupronickel objects now pinpoint the presence of this technology to regions spreading out from the Halys basin from the Old Kingdom Hittite period.
\end{abstract}

\section{Özet}

Bu makalede, Eski Hitit Dönemi'ne (yaklaşık M.Ö. 16. yy) tarihlenen Hüseyindede (Çorum, Türkiye) yerleşiminde ele geçen maden eserlerin arkeolojik ve analitik verileri sunulmaktadır. Kırsal olarak tanımlanabilecek bir alanda konumlanmış olan Hüseyindede yerleşimi, Erken Tunç Çă̆ı III (M.Ö. 26./25.-22./21. yy) ve Assur Ticaret Kolonileri Çağı'dan (M.Ö. 20.-18. yy) Hititlerin ortaya çıkışına kadar geçen süreçte, maden alaşımlama teknikleri açısından bir sürekliliğin var olduğunu ortaya koymaktadır. Dönemin bilinen alaşımlama tekniklerinin yanı sıra Hüseyindede'de, kupro-nikel olarak isimlendirilen ve Geç Tunç Çağı'nda Hititlerin başkenti Boğazköy/Hattuša'dan bilinen bakır-nikel alaşımlarının en erken örneklerinin bulunduğuna dair kanıtlar, bu çalışmada sunulmaktadır. Hüseyindede'de ortaya çıkarılan kupro-nikel eserler sayesinde bu alaşımlama teknolojinin, Kızılırmak kavsi içerinde Eski Hitit Dönemi'nden itibaren bilindiği saptanmıştır.

$\mathrm{M}$ etals and metallurgy played a significant role in the social, economic and political settings of the Hittite community. Various metals, including gold, silver, copper, lead, tin and iron, are recorded in written documents spanning the period between the 17th and 12th centuries BC (Siegelová, Tsumoto 2011: 276), though surviving metal artefacts are relatively rare. Of these 500 years of Hittite presence, however, little is known about the Old Hittite period, following the emergence of the kingdom in ca $1650 \mathrm{BC}$, when independent city-states of central Anatolia were united. Compared to the vast quantity of metallurgy related written records and archaeological finds from the first quarter of the second millennium $\mathrm{BC}$, namely during the Assyrian Trading Colonies period (ca 20th-18th century BC), those from the succeeding Old Hittite period (ca 17th-16th century BC) are sparse, perhaps due to the low number of archaeological sites that have been excavated. Archaeological studies, as well as archaeometric analyses of actual artefacts, are thus restricted due to the limited number of finds dated to this period. Hüseyindede, with its small but informative artefact assemblage, is, however, one of the few settlements found that can contribute to an understanding of Old Hittite metallurgy.

Hüseyindede (also 'Hüseyinbaba' on maps) is located ca $2.5 \mathrm{~km}$ southwest of the town of Yörüklü in the Sungurlu district of Çorum (Turkey) (fig. 1). It is situated on the southern top of the calcareous hill of Ağburun, which rises above a valley watered by the Acısu stream. This stream flows north to south, spilling into the Delice river (Yıldırım, Sipahi 1999; 2001; 2002). Excavations at the site were conducted between 1998 and 2004, under the direction of the Çorum Museum with the project led by Tunç Sipahi and Tayfun Yıldırım of Ankara University. 

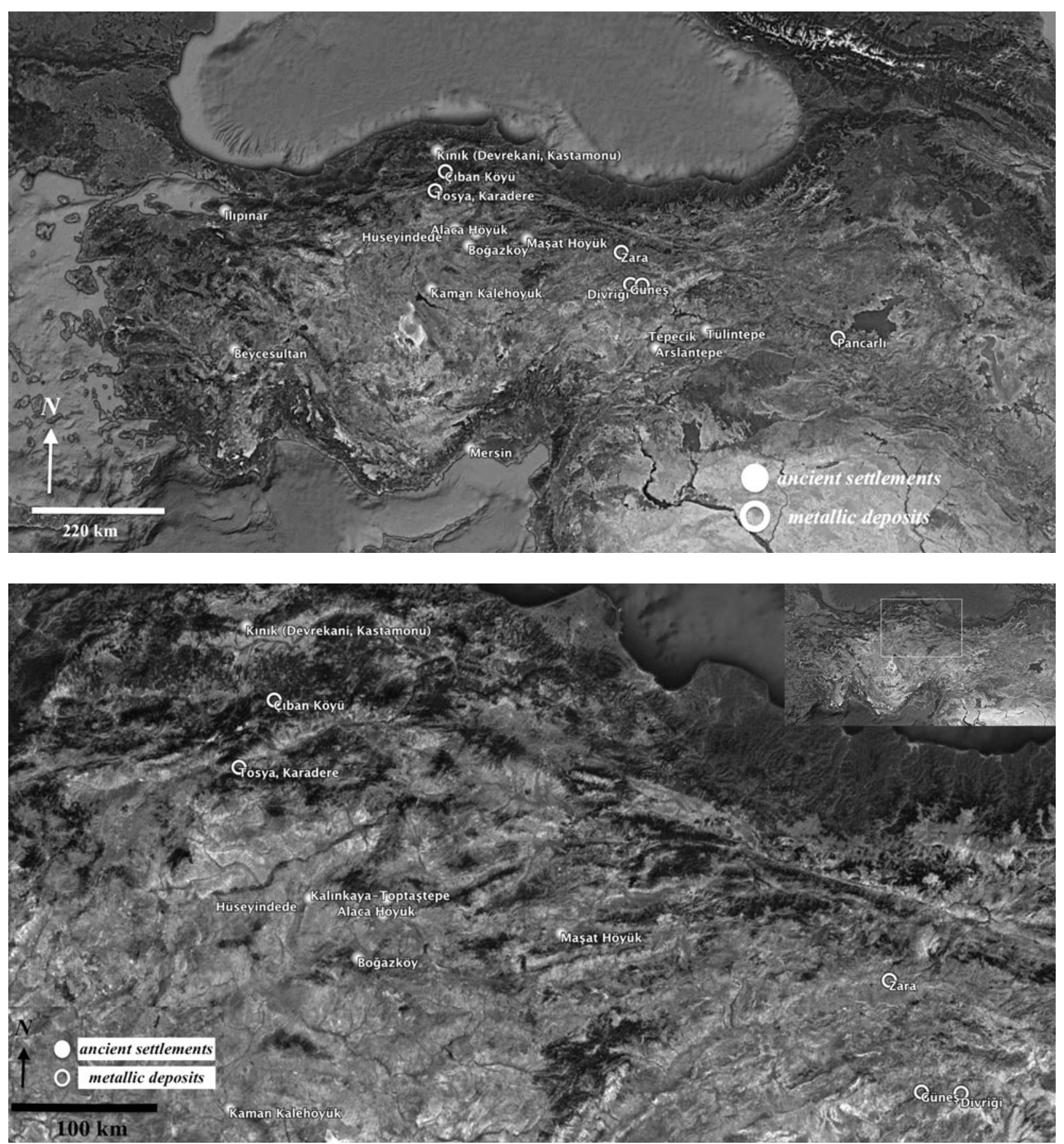

Fig 1. Anatolian sites and ore sources mentioned in the text (top) and sites and ore sources located in the Halys basin (bottom).

The excavations at Hüseyindede yielded material evidence for occupation during the Early Bronze Age, Old Hittite and Roman periods. However, because the site has been heavily damaged due to erosion, modern agriculture and illicit excavations, not much survives from these periods. Nevertheless, artefacts dated to the Old Hittite level of the site have proved to be very informative, particularly since so little is known about this period of Hittite history. The Old Hittite remains presented as one archaeological phase and demonstrate the presence of a rural settlement at Hüseyindede. The material evidence suggests continuity of local Hatti traditions known from the region (Y1lırım 2013a: 230-31). The site apparently later lost its importance during the Hittite Empire period (Yıldırım 2013a: 231).

Hüseyindede has attracted particular attention within the archaeological community due to the discovery of relief vases and fragments; two have been almost completely reconstructed, whilst the others survive as sherds. Details of the typologies and iconographies of the 
Hüseyindede vases have been published elsewhere (Sipahi 2000; Y1ldırım 2001; 2002; 2013a; 2013b). The vases, along with the associated ceramic assemblage and architectural levels, have been dated to the 16 th century BC with relative chronology.

The relative dating of the Old Hittite Hüseyindede material mainly centred on comparisons of the material with the İnandiktepe vase, which presents typologically parallel features. The İnandiktepe vase has been dated to ca $1650 \mathrm{BC}$, to the period of Hattušili I, based on a land donation document (Özgüç 1988). Gernot Wilhelm (2005), however, later dated the document to the reign of Huzziya I or, at earliest, Ammuna. Following the calibrated middle chronology, the reigns of these two successive kings have been placed in the 16 th century $\mathrm{BC}$, providing the chronological range for Hüseyindede (Yıldırım 2009: 246). The chronological attribution of the Hüseyindede material to the 16 th century $\mathrm{BC}$, according to the middle chronology, is not only based on the İnand1ktepe vase, but also on typological comparison of the Hüseyindede material with the well-stratified and dated Old and Middle Hittite material corpora of Kuşakl1, Sarišša (Mielke 2006; Yıldırım 2013b: 82). Likewise, the ceramic assemblage of Hüseyindede also indicates strong parallels to those of the İnandiktepe temple (Özgüç 1988: 9-24) and Alaca Höyük IIIa-b (Y1ldirım 2009), supporting a date of the 16th century BC (Yıldırım, Sipahi 2001: 317).

While the relief vases and chronology of Hüseyindede have attracted the attention of scholars, the metal artefacts have been overlooked, mostly due to the minute number of objects recovered. This paper presents archaeological and archaeometric information on the complete metal corpora of Old Hittite Hüseyindede, which, unfortunately, is composed of just four pieces. The analytical results provide the first insights into Old Hittite metallurgy.

\section{Archaeological material}

The Hüseyindede excavations yielded five metal artefacts in total. One, a buckle (Çorum Museum study collection number 923; table 1), is a modern surface find recovered in the course of the 2002 season (Sipahi 2003: 181, 186, fig. 7). Some areas have a golden appearance. Later confirmed by scientific analysis to be made of brass, an alloying technology unusual for the second millennium BC, the sharp and smoothly cut pointed ends of the artefact indicate modern production techniques. Since this is considered to be a modern object, it will not be discussed further.

The four ancient metal artefacts comprise a dagger fragment (Çorum Museum study collection number 916; excavation code Etd 99/21), two pins (Çorum Museum inventory number 7019; excavation code HD.2001/2 and Çorum Museum inventory number 7020; excavation code HD.2001/3) and a nail head (Çorum Museum inventory number 7021; excavation code HD.2001/4). Hereafter, the artefacts will be referred to by inventory or study collection number. The dimensions of the items are listed in table 1. The artefacts and their find-spots are presented in figures 2 and 3 , respectively.

The dagger fragment (916) was recovered from the floor level of Building III, a multi-roomed Hittite house (fig. 3). It is $10.7 \mathrm{~cm}$ long, $3 \mathrm{~cm}$ wide and weighs $78.05 \mathrm{~g}$. The artefact is not complete, though the hilt, with a single rivet, has survived (fig. 2c). The sides of the hilt, which thin at the edges, were widened by hammering (Y1ldırım, Sipahi 2001: 321-33, fig. 8, pl. 2). Close parallels of this dagger have been found at Alaca Höyük IIIa-b (Koşay, Akok 1966: 77, pl. 133:5; Erkanal 1977: 36, pl. 13:30; Yıldırım, Sipahi 2001: 321). The Boğazköy (Boehmer 1972: 44, Taf. IV:54, Assyrian Trading Colonies period) and Alişar (von der Osten 1937: 253, fig. 287:d2567) daggers are similar, but reveal a slight difference with the existence of two rivets (Yıldırım, Sipahi 2001: 321).

\begin{tabular}{llccccc}
$\begin{array}{l}\text { Corum Museum } \\
\text { number }\end{array}$ & Object type & Length $(\mathrm{cm})$ & Width $(\mathrm{cm})$ & Weight $(\mathrm{g})$ & $\begin{array}{c}\text { Diameter of } \\
\text { Shaft }(\mathrm{cm})\end{array}$ & $\begin{array}{c}\text { Diameter of } \\
\text { head }(\mathrm{cm})\end{array}$ \\
\hline 916 & Dagger fragment & 10.7 & 3.0 & 78.05 & $\mathrm{n} / \mathrm{a}$ & $\mathrm{n} / \mathrm{a}$ \\
923 & Buckle & 4.0 & 2.0 & - & $\mathrm{n} / \mathrm{a}$ & $\mathrm{n} / \mathrm{a}$ \\
7019 & Pin & 16.9 & $\mathrm{n} / \mathrm{a}$ & 6.75 & $0.2-0.3$ & $0.4-0.6$ \\
7020 & Pin & 9.0 & $\mathrm{n} / \mathrm{a}$ & 2.85 & 0.2 & 0.5 \\
7021 & Nail head & 3.3 & $\mathrm{n} / \mathrm{a}$ & 34.20 & $0.7-0.8$ & $\begin{array}{c}3.6-3.7 \text { with a } \\
\text { thickness of } 0.5\end{array}$
\end{tabular}

Table 1. Artefact types and dimensions (- not measured). 


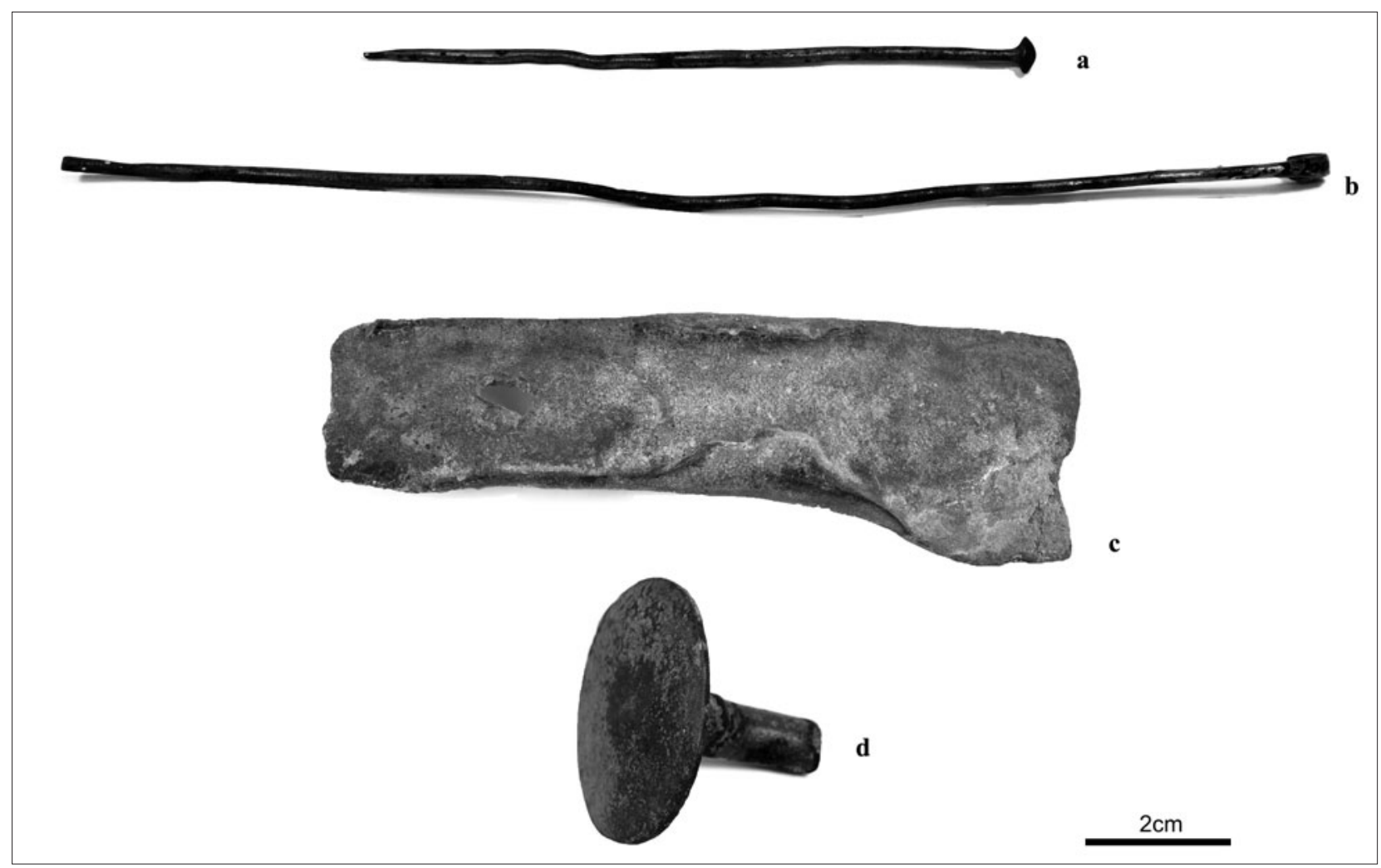

Fig 2. The Old Hittite metal corpora of Hüseyindede: (a) 7020, pin; (b) 7019, pin; (c) 916, dagger; (d) 7021, nail head.

Pins 7019 and 7020 were both recovered from the fill in the western part of Building IV, in square $3 \mathrm{~b}$ (fig. 3). They have a silvery appearance. Both are recorded as bronze in the museum records. However, the museum inventory forms documenting the two pins were misplaced, and thus the information on 7019 appears in the record of 7020 and vice versa. The confusion is resolved here through re-examination of the original artefacts. Pin 7019 is $16.9 \mathrm{~cm}$ long, though not straight, and the point is broken (fig. 2b). It has a round cross section $0.2-0.3 \mathrm{~cm}$ in diameter. The head of the pin has been hammered, flattened and rolled into a spiral, which measures $0.4 \mathrm{~cm} \times 0.6 \mathrm{~cm}$. The pin weighs $6.75 \mathrm{~g}$. A parallel, though shorter $(4.9 \mathrm{~cm})$, was found in the temple context of İnandıktepe and documented as bronze (Özgüç 1988: 45, pl. 65:1). Furthermore, the Late Bronze Age levels of the Sarıkale valley of Boğazköy yielded a similar type of pin (Bo. 09/972: Lehner 2015: 165, 167, fig. 5:10, 12). This typology is not characteristic of the Hittite period, but was common in the Early Bronze Age, in the Halys basin and beyond (Ahlatlibel: Koşay 1934: 77, res. A, B, 356; Kayapınar: Temizer 1954: 327, lev. 19d; İkiztepe: Alkım et al. 2003: 107, lev. LXV:18).

Pin 7020 is $9 \mathrm{~cm}$ long and tapers to a point (fig. 2a). The cross section of the shaft measures $0.2 \mathrm{~cm}$. The head is conical in shape and measures $0.5 \mathrm{~cm}$ in diameter. The pin weighs $2.85 \mathrm{~g}$. A typological parallel is documented from the Late Bronze Age levels of Boğazköy (Lehner 2015: 167, fig. 5:12). Similar to 7019, these types of conical-headed pins are known from the region since the Early Bronze Age, indicating continuity in typology. Both pins are recorded as bronze in the museum records and are on display in the Hüseyindede showcase at the Çorum Museum.

Along with the pins, a nail head (7021) was also found in the western part of Building IV in square $3 \mathrm{~b}$ (fig. 3). Its shape resembles a mushroom (fig. $2 \mathrm{~d}$ ), with a diameter of $3.6-3.7 \mathrm{~cm}$ and a thickness of $0.5 \mathrm{~cm}$. The shaft is broken; nevertheless, the intact piece measures $3.3 \mathrm{~cm}$ in length and $0.7-0.8 \mathrm{~cm}$ in diameter. It weighs $34.20 \mathrm{~g}$. The head of the nail has a noticeable silvery sheen and the surface is quite irregular, due to corrosion. This artefact is also recorded as bronze in the museum records and sits in the Hüseyindede display at the Çorum Museum, along with the pins.

As the two pins and nail head were recovered from the same fill context, it is important to define the function of Building IV in order to understand the characteristics of the artefacts, characteristics which have led us to attribute the artefacts to Building I, rather than IV.

Building IV has also been referred to as Complex IV. It measures $16 \mathrm{~m} \times 7.5 \mathrm{~m}$ and has an almost rectangular shape. It has been identified as a section of a multi-roomed Hittite house, which, typically, feature a small square 
connecting courtyard and rectangular and/or L-shaped rooms (fig. 3; Yıldırım, Sipahi 2002: 260). Similar architectural models have been discovered at Alaca Höyük in levels IIIa-b, dated to the Hittite period (Koşay, Akok 1966). The function of Building IV as a house rather than a building associated with the temple is confirmed by several factors, including the nature of the in situ ceramic assemblage. This is composed of rough and regular kitchenware only, clearly designed for daily use. In contrast, the ceramic assemblage of Building $\mathrm{I}$ is of a cultic nature, exemplified by the relief vases and high-quality ceramics recovered in situ from the depot areas of the building (Y1ldırım, Sipahi 2001: 316-24). In addition to the differentiation between the ceramic repertoires of the two complexes, Building IV and Building I were located at different elevations (fig. 3).
The Old Hittite level of Hüseyindede is secure in terms of chronology, since the Old Hittite occupation has been demonstrated as being limited to one phase; nevertheless, the find context of the metal artefacts should be discussed in more detail in order to understand fully their original functions and context.

Building IV is located to the west of Building I, which is, in turn, located at the highest point of the hill that dominates the entire valley and is identified as the temple or cultic area of the settlement (Sipahi et al. 2000; Y1ldırım 2000; 2013a; 2013b; Y1lırım, Sipahi 2001; Sipahi 2003). An evaluation of the topography is critical here in order to interpret clearly the secondary context(s) of the artefacts. As noted above, the two pins and the nail head were not recovered in situ, but from the fill in the western part of Building IV. They were found alongside a libation cup and

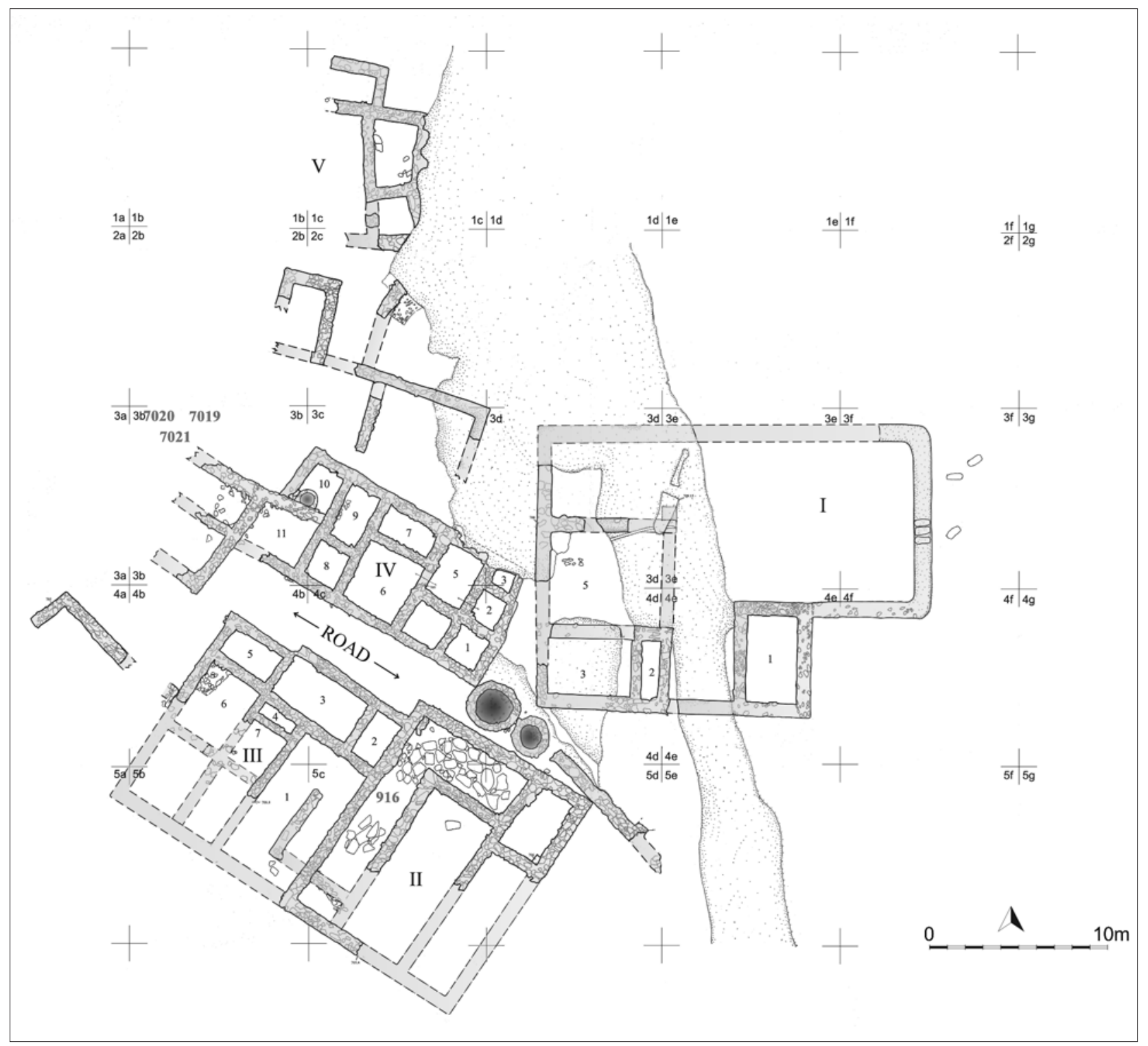

Fig 3. Architectural plan of Hüseyindede: Old Hittite phases with find-spots of the metal artefacts (after Ylldırım 2013a). 
a relief-vase fragment. Libation cups and relief vases form part of the cultic assemblage recovered in association with Building I. Considering the cultic nature of the ceramics found in relation to these metal artefacts, in contrast to the everyday characteristics of the in situ ceramics of Building IV, we suggest that the primary context of the two pins and the nail head must have been Building I, namely the temple area. Our suggestion is based on both the secondary contexts of these items and their associated ceramic material. As stated above, the assemblage of Building I comprises such ceramics, and it has been identified as a temple/cultic area. Due to the topography of the site, heavy erosion and ploughing activities, it is suggested that artefacts originally placed in the depots of the temple (i.e. Building I) slid downhill towards Building IV, which, rather than having a cultic function, was a typical Hittite house. This scenario also explains the secondary fill context of the metals in association with cultic ceramics. The association of these pins with the temple, rather than with a house, also concords with the evidence from Inandiktepe, where similar pins were recovered from the temple context (Özgüç 1988).

\section{Research context}

The Hüseyindede metal assemblage is a very small data set. Nonetheless, since so little archaeological material from the Old Hittite period has been analysed and published, the data and results presented in this study still make a significant contribution to the body of knowledge of Old Hittite metallurgy, as well as indicating its significance among the alloying traditions of Anatolia.

This research relates to the exciting topic of the use of copper-nickel alloys - also known as cupronickel alloys which has risen to prominence recently in studies focused on Hittite metallurgy. Thus, cupronickel Hittite artefacts have previously been identified (Bachmann 1984; Lehner 2012). Recent research on Late Bronze Age metal artefacts from Hattuša has demonstrated the existence of cupronickel objects, including mostly sheet pendants, pins and seals (Lehner 2014: 132; 2015: 163). In-depth analysis of a rolled pin (Bo 09/972), a close parallel to Hüseyindede pin 7019, identified the presence of cupronickel containing levels of nickel higher than 20wt\% (Lehner 2014: 136, fig. 64; 2015: 165, fig. 5:10). Several other Boğazköy pins, including one very similar to Hüseyindede 7020, were also identified as high-nickel cupronickel with more than 10wt\% nickel (Lehner 2015: 167, fig. 5:12).

Among the items of the significant cupronickel alloy assemblage from Boğazköy, a lunula pendant (Bo 08/9), containing $13.5 \mathrm{wt} \%$ nickel and $1.3 \mathrm{wt} \%$ arsenic, was found at Sarikale (Schachner 2009; Lehner, Schachner 2017: 412). The $6.49-7.17 \mathrm{wt} \%$ nickel and $0.90-0.93 \mathrm{wt} \%$ cobaltbearing chain links of the treaty tablet of Tuthaliya IV and
Kurunta of Tarhuntašša (Otten 1988) must also have been cupronickel, even though Thomas Zimmermann and colleagues (2010: 228) consider the nickel to be a natural contamination of the copper ore, proposing that around $7 \mathrm{wt} \%$ nickel added to copper does not have an effect on the object's colour. Given the silvery appearance and possibly the surface texture of cupronickel, its use could indicate a deliberate intention to produce artefacts holding religious and political significance.

All the cupronickel artefacts from Boğazköy are dated broadly to the Late Bronze Age, for which an interval of ca 1650-1200 BC is postulated (Lehner, Schachner 2017: 409). None of them is specifically attributed to the Old Hittite period, which leads to the assumption that a great number of them must date to the Hittite Empire period. It is also important to remember that, with regards to the Old Hittite levels of Boğazköy, there is some evidence, based on archaeological finds such as tuyeres, to suggest the existence of a metal workshop (Müller-Karpe 1994: 7273 ), though the exact nature of any metallurgical practices is not yet known.

A significant group of metal artefacts, including rhytons, a tripod, bowls, jugs, bullheads and bullhorns, was recovered from a pit during construction work at the Kulaksizlar dam in Kastamonu (Turkey). These artefacts, known as the 'Kastamonu-Kınık metals' in the literature, are dated to the 14 th/13th century BC, based mostly on their typologies and iconographies (Emre, Çınaroğlu 1993), as well as on a Luwian inscription on a bowl known as the 'Taprammi bowl' (Hawkins 1993). Preliminary unpublished portable X-ray fluorescence (pXRF) analysis of these items by Yildirım and his team shows that some of them, particularly the horn fragments, were made of ca $10-15 \mathrm{wt} \%$ nickel, resulting in a silvery colour which, from the Early Bronze Age, was associated with fashion and/or religious symbolism, as demonstrated by the silver-horned bull and stag statues of Alaca Höyük (Koşay, Akok 1966). A potentially similar scenario also explains the preliminary identification of Kınık metals as possibly silver (Çınaroğlu 1990-1991: 53). Kutlu Emre and Aykut Çınaroğlu (1993: 678) later stated that the animal-shaped vessels of the Kınık assemblage were initially believed to be silver, though they revealed a different hue after cleaning. They propose that the vessels were possibly made of an alloy of copper and silver by drawing a parallel in terms of physical appearance to a Boğazköy fragment, though they do not identify the fragment they refer to (Emre, Çınaroğlu 1993: 678). An extended study of a new metal group from Kınık is ongoing.

It is worth mentioning here that a salvage excavation conducted in the Kastamonu Devrekani province yielded metal furnaces, crucibles, slags and metal artefacts (Bilgen 1999: 277). These finds, recovered over the 
course of two excavation seasons (1994 and 1995), are roughly dated to the second millennium BC (Bilgen 1999: 277), although this chronology has been challenged and the finds attributed to the late third to early second millennium BC (Genç 2008: 113). Based on the production debris and its associated assemblage, the existence of a possible metal workshop at the site has been proposed (Bilgen 1999; Genç 2008: 112). A. Nejat Bilgen suggests that the metals were sourced from Mount Küre, the presumable source of copper for the objects of the Kinık hoard (Bilgen 1999: 278). However, these arguments still await archaeological and archaeometric confirmation, and questions remain about the chronology of the KastamonuKınık excavations.

Three examples dated to the second and first millennia BC with a content of $12 w t \%, 20 w t \%$ and $28 w t \%$ nickel have been documented at Kaman-Kalehöyük (Kırşehir, Turkey) (Hirao, Enomoto 1997: 194-95, table 5). Even though the chronology of Kaman-Kalehöyük remains under study (Matsumura 2008), the existence of cupronickel alloys in the Iron Age levels indicates the continuation of this technology.

There are also some unprovenanced examples of cupronickel artefacts attested to the Hittites. A bracelet with an electrum repoussé inlay from the province of Çorum contains around $16.5 \mathrm{wt} \%$ nickel and $2 \mathrm{wt} \%$ cobalt. The band of the bracelet indicates a composition of $0.14 \mathrm{wt} \%$ arsenic and $0.59 \mathrm{wt} \%$ iron as impurities related to the smelting of the mixed ores (Lehner 2014: 136; forthcoming). After careful examination and comparison of its iconography to seals and seal impressions, this bracelet has now been dated to the 13th century BC (İpek, İbiş forthcoming). Another unprovenanced example, of a bull, believed to be Hittite and dated to the end of the second millennium $\mathrm{BC}$ has been found to contain $17.7 \mathrm{wt} \%$ nickel and $2.1 \mathrm{wt} \%$ cobalt. Thanks to its metallography, cobalt precipitated from the solid solution in the cupronickel was detected (Northover 1998: 119-20). J. Peter Northover also notes what is believed to be a Hittite ring found near Haifa (Israel) with similar characteristics. No further information on the ring is available (Northover 1998), and it is important to note that relying on unprovenanced artefacts is risky in terms of establishing a definite chronology with which to contextualise the development of cupronickel technology in Anatolia over the course of the latter half of the second millennium BC.

Questions concerning the production technology and metal sources arise alongside the accumulating information on the cupronickel phenomenon of Anatolia. Joseph W. Lehner (2015) proposes that a mixed ore smelting process was used in the production of Late Bronze Age cupronickel artefacts from Boğazköy. He suggests that the smelting of sulphides, such as arsenopyrites and chalco- pyrites, together with nickel and cobalt-rich minerals, such as pentlandite $(\mathrm{Fe}, \mathrm{Ni})_{9} \mathrm{~S}_{8}$ and siegenite $(\mathrm{Ni}, \mathrm{Co})_{3} \mathrm{~S}_{4}$, might have been practised. He points to two possible sources one is a copper-nickel deposit located at Pancarlı, Bitlis, with a composition of 1-4\% nickel (Hirano, Boyalı 1980; Çağatay 1987) and the other is a nickel-iron sulphide source found at Divriği, Sivas Güneş (Meyer 1967: 57) as well as at Han Deresi (Harada et al. 1971). In addition to Lehner's suggestions of Pancarlı and Divriği as potential sources of copper-nickel ores, Kastamonu Çıban Köyü (Pilz 1937) and Tosya, Karadere (Ayaroğlu 1980), have also yielded nickel-bearing mineralisations, though, due to their limited economic value, they have not been investigated (geologically or archaeologically) in detail. Nevertheless, the archaeological importance of any possible ancient use of copper-nickel ores in close proximity to Kastamonu and Tosya is discussed below.

\section{Methodology}

Over the last decade, the use of pXRF has become increasingly common in the field of archaeology for the study of various types of artefacts and materials, as it is effective in terms of both time and cost. The obvious main benefit of pXRF analysis is that it is non-destructive and portable; thus, analyses can be conducted within museums, for example, rather than being limited to laboratories (Frahm, Doonan 2013). This method is the only one possible for the compositional analysis of museum-housed objects in Turkey, where permits are restricted and controlled, with tight regulations regarding the movement of artefacts (Massa et al. 2017). The analyses of the Hüseyindede artefacts were conducted in July 2017, in the Çorum Museum depot. The necessary permissions were obtained in advance, and the rules and regulations of the Turkish Ministry of Culture and Tourism were followed precisely.

Quantitative analyses of the Hüseyindede metal artefacts are theoretically possible with calibrations of pXRF; hence, these previously unpublished materials present a significant set of data on Old Hittite metals. However, pXRF is a surface-analysis technique and can be used to analyse to a depth of approximately $0.05 \mathrm{~mm}$ only, depending on the target element and matrix of the artefact. The technique cannot, therefore, provide bulk compositions for the objects. Confirmation of the bulk analysis or metallurgy of the artefacts through destructive methods or metallography was not possible, due to limitations in the allocation of museum-based research permits.

A portable Bruker Tracer SD-IV X-ray fluorescence spectrometer ( $\mathrm{pXRF}$ ) was used for the analysis of the Hüseyindede metal artefacts. The X-ray tube type used was a rhodium target. $40 \mathrm{kV}$ and $15.80 \mu \mathrm{A}$ were selected under air (non-vacuum), with a titanium-aluminium filter of $25 \mu$ titanium in layer 1 and $300 \mu$ aluminium in layer 2 . 
This is the automatic filter specification of the instrument in filter number one and is the standard setting of the instrument used for metal analysis. The instrument was calibrated according to copper alloy standards BCR 691 A, C, D and BAM 211. Analysis time was adjusted to 180 seconds. Each reading was repeated three times to obtain an average. The analysis points and results are detailed in table 2 .

Analyses were conducted on a stand in order to minimise any instability caused by vibration of the instrument. All surfaces of the artefact were mechanically cleaned in the Çorum Museum or in collaboration with the central restoration unit of the Anatolian Civilizations Museum, Ankara; severe corrosion was not visible on the surfaces. For pXRF analysis, the size of the surface to be analysed should accord with the window of the instrument's detector; this prevents measurement of a void and/or background, and thus provides more accurate results. For the Hüseyindede assemblage, the instrument window was indeed filled with the surface to be analysed; thus distortion in the results is unlikely. This set-up is comparable to those of other projects using a similar methodology - for example, the pXRF analysis of a western Anatolian Early Bronze Age assemblage (Massa et al. 2017). However, calibration techniques and analysis time do differ. Rather than relying on prior analysis conducted on artefacts, this study used calibration standards, and the analysis time was doubled in order to collect as many electron counts (i.e. elemental signals) as possible.

\section{Results}

The pXRF results (table 2) demonstrate that all the Old Hittite Hüseyindede metal artefacts are copper-alloys, among which the existence of cupronickels is significant for the Old Kingdom period.

The dagger (916) was analysed at three different points, selected on the hilt and the blade. The results show a composition of $85.87-90.20 \mathrm{wt} \%$ copper, with 4.07 $6.87 \mathrm{wt} \%$ tin, indicating that the dagger is bronze. This amount of tin would also make the object harder. In addition, the artefact displays various amounts of arsenic and antimony at different analysis points $(2.65 \mathrm{wt} \%$ arsenic, max.; $1.97 \mathrm{wt} \%$ antimony, max.). These amounts of arsenic and antimony suggest the possibility of recycling or the existence of heterogeneous alloying practices, as well as the practice of using copper acquired from different sources or the use of arsenic containing copper ore (Tylecote et al. 1977; Pernicka 1990). It is not possible to propose details regarding the production technology of the dagger without conducting metallography, though the features of the blade indicate casting, followed by hammering.
The pins were analysed at two points. Pin 7019 contains $8.12-8.36 \mathrm{wt} \%$ nickel, as well as approximately $1 \mathrm{wt} \%$ arsenic. The second pin (7020) contains $12.11-$ $12.36 \mathrm{wt} \%$ nickel. In the literature, values higher than $1 \mathrm{wt} \%$ nickel in copper are considered to demonstrate cupronickel alloys. One to $10 \mathrm{wt} \%$ nickel-containing alloys are characterised as low-nickel cupronickel, whereas alloys containing more than $10 \mathrm{wt} \%$ nickel are defined as high-nickel cupronickel (Lehner 2015: 161; forthcoming). Hence, Hüseyindede pin 7019 may be characterised as a low-nickel and pin 7020 as a high-nickel cupronickel alloy. The cupronickel alloys are often correlated to a composition of $1-2 \%$ cobalt and impurities of iron, both of which have higher solubility in nickel than copper (Lehner 2015: 158; Lehner, Schachner 2017: 412). However, for the Hüseyindede artefacts, cobalt $(0.27 \mathrm{wt} \%$, max.) and iron $(0.96 \mathrm{wt} \%$, max.) impurity levels are detected as lower than $1 \mathrm{wt} \%$. Such depressed levels of impurities may be due to the surface-only analysis of the pXRF method, as well as the lack of cobalt in calibration standards. For cobalt only, values obtained with standardless measurements are listed in table 2. Since metallographic examination of these artefacts was not possible, evidence explaining the lowerthan-expected impurity levels for cobalt and iron cannot be offered at this point in time.

The head and shaft parts of the nail head (7021) were analysed separately, both at two points. As the head has an irregular surface colour and texture, one of the points of analysis was located on the relatively smooth area (point 1) and a more corroded point (point 2) was selected for the second (fig. 4). The results of these two analyses differ significantly in terms of tin content. The analysis at point 1 shows a composition of $21.83 \mathrm{wt} \%$, whereas point 2 contains more than double the proportion of tin $(48.8 \mathrm{wt} \%)$.

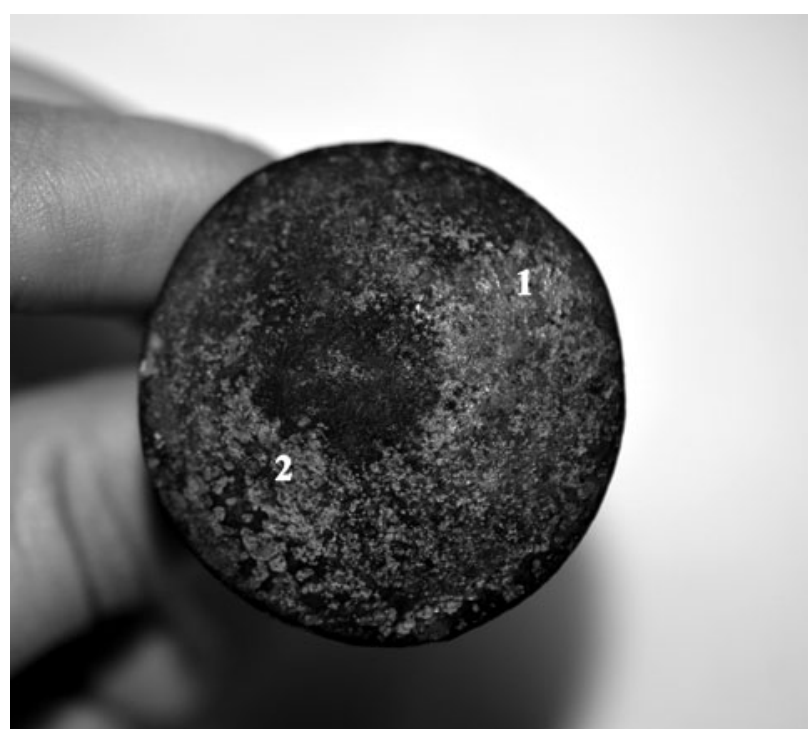

Fig 4. The points of analysis of the Hüseyindede nail head. 


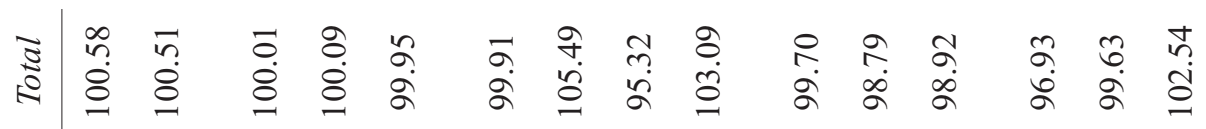

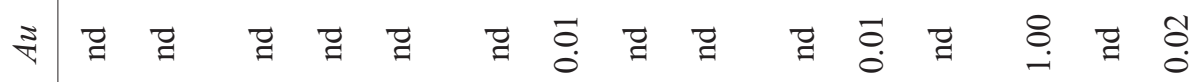

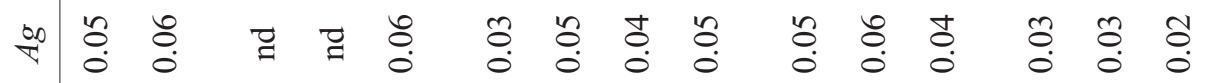

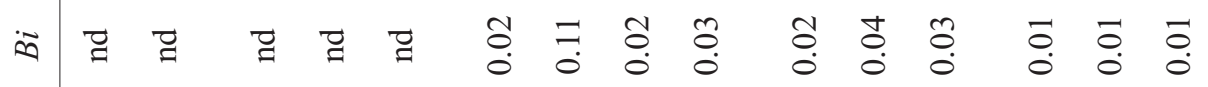

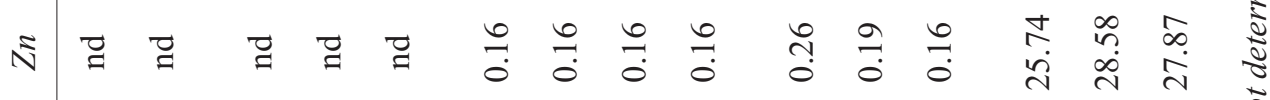

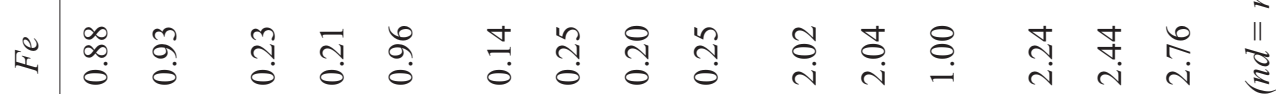

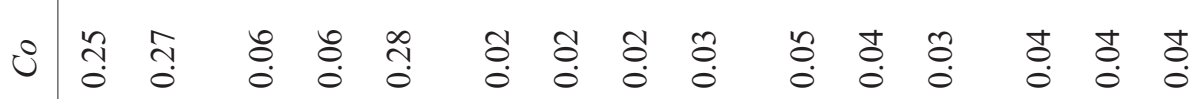

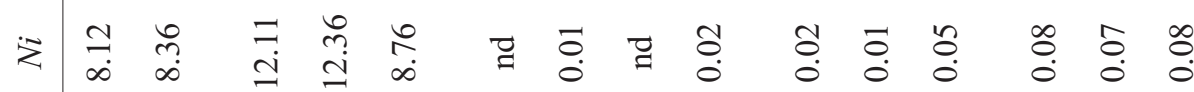

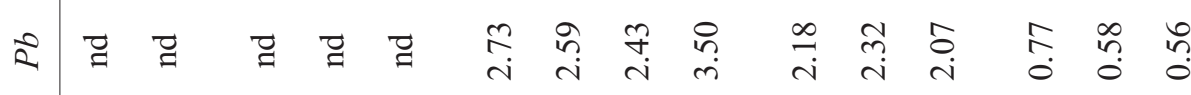

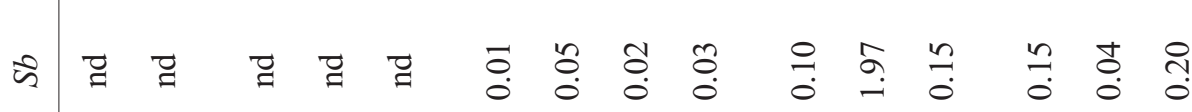

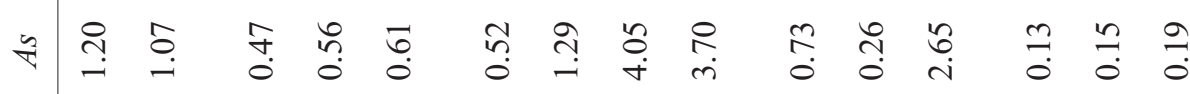

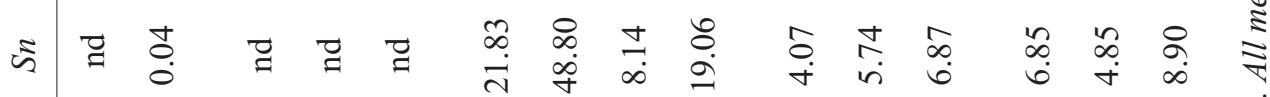

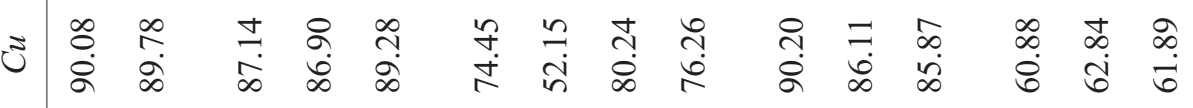

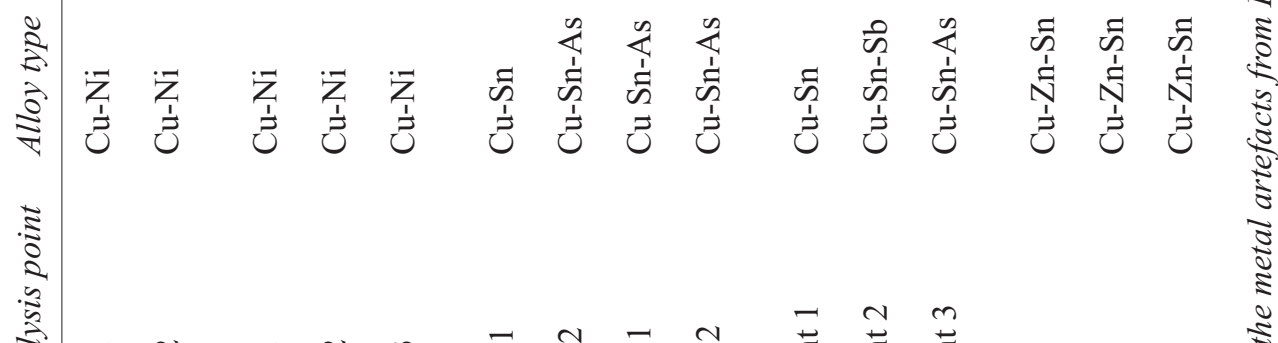

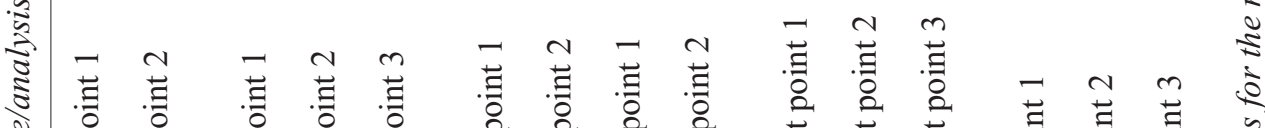

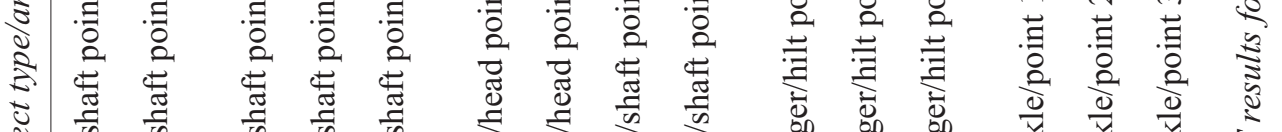

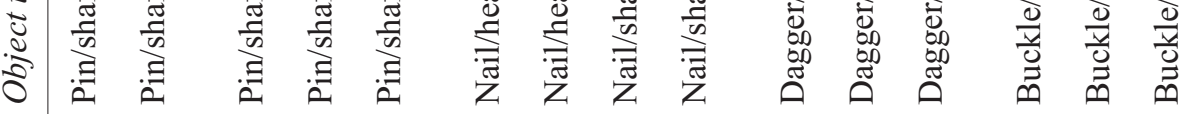

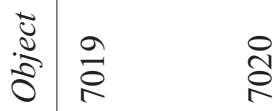

$\bar{\varsigma}$

$\frac{0}{\sigma}$

๙ู 
The high proportion of tin found at point 1 could be related to the creation of a silvery appearance (still partially visible on the object) and confirm what has been considered a deliberate practice in central Anatolia since the Early Bronze Age (Zimmermann, Yildırım 2008). However, the presence of almost $50 \%$ tin is only explicable by the surface segregation of tin over time, a known phenomenon for archaeological bronzes (Tylecote 1979; Meeks 1986).

The shaft parts were determined to be made of coppertin-arsenic ternary alloy. The arsenic proportions were determined to be $3-4 \mathrm{wt} \%$, whereas the amount of tin again varied between $8.14 \mathrm{wt} \%$ and $19.06 \mathrm{wt} \%$. The shaft of the artefact has a less corroded surface; thus, such a variation in the amount of tin might be related to intentional alloying to create a silvery colour or might simply indicate the segregation of tin in the bulk composition of the surface. At this stage of the collection of archaeometric data, the shaft can be identified as a ternary alloy, without further attestations to its tin content.

\section{Discussion}

Compositional analysis of the finished metal artefacts from Hüseyindede offers limited but expedient information on the alloying practices of the Old Hittite period. No metal workshops have been uncovered at the site, although two ceramic kilns have been identified in proximity to Building I. There are also no available written documents. Thus, any arguments regarding sponsorship, state control or the organisation of metal production at Hüseyindede remain hypothetical. Nonetheless, the analytical results offer clues about possible networks and trade relations, which must have been established before the Hittite Empire period (14th -13 th century BC), for which a complex organisation of metal production has been demonstrated (Lehner 2015; Lehner, Schachner 2017).

Setting the buckle (923) aside as a modern object, there are only four metal artefacts from Hüseyindede, but they do serve as evidence for alloying traditions. Varying from ternary bronzes to cupronickel alloys, these metal objects demonstrate complex technological practices that might be related to the recycling or use of different resources.

The dagger (916) and the nail shaft (7021) evidence the use of bronze at Hüseyindede. The dagger contains varying values of $4.07-6.87 \mathrm{wt} \%$ tin and $0.26-2.65 \mathrm{wt} \%$ arsenic. The existence of such amounts of arsenic in copper as either an impurity or an intentional alloying element has long been debated. James Muhly (1985: 127) records anything containing over $1 \mathrm{wt} \%$ arsenic as a deliberate alloy. N.H. Gale and colleagues (1985: 154-55) have responded to his argument by pointing to a $7 \mathrm{wt} \%$ arsenic content (or up to $7 \mathrm{wt} \%$ ) in copper obtained by the smelting of arsenic-bearing copper ores, as well as by citing
Tylecote et al. 1977, which reveals direct smelting resulting in the acquisition of almost $4.2 \mathrm{wt} \%$ arsenic. Heather Lechtman (1996: 509), however, records a range of $0.5-2 \mathrm{wt} \%$ arsenic in intentional alloying. Lechtman (1981; 1996) classifies $0.1-0.5 \mathrm{wt} \%$ arsenic-containing metals as 'low arsenic-copper alloy' and those with 0.5 $7 \mathrm{wt} \%$ arsenic content as 'arsenic bronze'. Hence the existence of an average of $1.21 \mathrm{wt} \%$ arsenic in the Hüseyindede dagger could result from an impurity, intentional alloying, the use of recycling or the production of bronze from impure/already-arsenic-bearing copper. A definitive conclusion cannot be reached without first determining the source of the artefact, as well as the nature of ancient resources. Nonetheless, the existence of both arsenic and antimony (max. $1.97 \mathrm{wt} \%$ ) in the composition of the dagger favours the probability of the smelting of a Fahlerz-type ore (Pernicka 1990: 50). Since ternary alloys (copper-arsenic-tin) have been identified as early as the Early Bronze Age (Lehner et al. 2015: 203, 204, table 2; Dardeniz, Y1ldirım forthcoming), we argue that this alloying practice continued throughout the Old Hittite period. Both the alloy types and the typologies of the artefacts were continuous and exhibit similarities to a comparable dagger found in the Assyrian Trading Colonies levels of Boğazköy (Boehmer 1972: 44).

The high tin content of the nail head (7021) could be the cause of its silvery appearance. A silver-coated votive nail was discovered at the Hittite temple of Maşat Höyük (Tokat), dated to the 15th century BC (Özgüç 1994: 228). The associated assemblage includes a terracotta bull's head and leg fragments recognised to be parts of bull-shaped rhytons from Boğazköy and İnandıktepe (Özgüç 1994), indicating the cultic nature of the artefact (Dardeniz 2016: 38-39). Even though the Maşat Höyük votive nail has been dated to a later period, the silver coating of the artefact and its associated ceramic assemblage indicates connections to that from Hüseyindede.

Research on Hittite artefacts from Tülintepe and Tepecik (Keban, Elazığ) has revealed comparable results. Thirty-four metal artefacts from Tülintepe and Tepecik (including a piece of slag and a piece of galena) were analysed using atomic absorption spectroscopy. The results indicate that two of these artefacts were made of low-tin bronze, containing $1.1 \mathrm{wt} \%$ (T.69-989, nail) and 3.59wt\% tin (TL.71-251, metal fragment), and that four were made of arsenical copper (T.71-439, pin head; T.70-1038, pin?; T.69-241, metal fragment; T.70-1388, needle or pin), containing amounts of arsenic varying between 1.86 7.76wt\% (Çukur, Kunç 1989: 116-17, table 5). Even though the condition of the artefacts is documented as highly corroded (Çukur, Kunç 1989: 116) and the exact chronological interval implied for the Hittite period is not clear, a comparison of the Tülintepe and Tepecik analytical 
results with those from Hüseyindede suggests the existence of higher tin levels and ternary alloys at Hüseyindede.

Six metal artefacts from Ilıpınar in northwestern Anatolia, of which only four have secure archaeological contexts, were analysed using neutron activation analysis and were determined to be arsenical coppers with 3.01$5.75 \mathrm{wt} \%$ arsenic concentrations. Their tin levels are far below 1wt\% (Begemann et al. 1994: 211-12, tables 1, 2). Presumably dated to the Middle Bronze Age, these artefacts include axes, a sword and a dagger; the latter reveals different chemical and isotopic compositions at the blade and rivet sections, indicating metal sources from a different province (Begemann et al. 1994: 207). These low-tin Ilıpınar artefacts distinguish well from the metal artefacts from Hüseyindede.

Arsenical coppers with no-tin or low-tin contents have also been found in the Middle Bronze Age and Late Bronze Age levels of Mersin (Levels IX-X: ca 1800-1500 BC; Levels VII-VIII: 1500-1300 BC). A study of 21 objects from Levels IX-X, assessed using neutron activation analysis, demonstrates that 16 are made of arsenical copper containing $0.5-4.4 \mathrm{wt} \%$ arsenic, three contain $1-$ $4 \mathrm{wt} \%$ tin and $1-1.9 \mathrm{wt} \%$ arsenic, and two are high-tin bronzes containing $0.74 \mathrm{wt} \%$ and $2.2 \mathrm{wt} \%$ arsenic. Two artefacts dated to the Late Bronze Age (Levels VII-VIII) were found to be made of arsenical copper (Gale et al. 1985: 168). This same study suggests that arsenical copper artefacts, containing $0.7-1.5 \mathrm{wt} \%$ arsenic levels, were also common in the Middle and Late Bronze Age phases of Beycesultan, with the exception of two artefacts containing $0.35 \mathrm{wt} \%$ and $0.55 \mathrm{wt} \%$ arsenic, indicating the rare use of bronze at the site.

A comparative graph demonstrating the distribution of alloying practices at Hüseyindede and the aforementioned sites shows that the production of arsenical copper, bronze and ternary alloys were commonly employed metallurgical practices (fig. 5). Among the sites considered here, only Hüseyindede has yielded cupronickel artefacts. A study of 982 artefacts from the Late Bronze Age contexts of Boğazköy shows that alloying practices were not limited to these types but also include copper-arsenic-nickel, copper-arsenic-lead, copper-tin-lead, copper-tin-nickel, copper-arsenic-tin-lead, copper-nickel and copper-lead alloys (Lehner 2014: 146, fig. 60; 2015: 175, fig. 5:15). The complexity of the alloying practices and metal consumption strategies at Boğazköy during the Late Bronze Age has been studied in detail (Lehner 2014; 2015; Lehner, Schachner 2017) and is well beyond the focus of this study. Hence, figure 5 intentionally excludes results obtained from Late Bronze Age Boğazköy, where studies are ongoing.

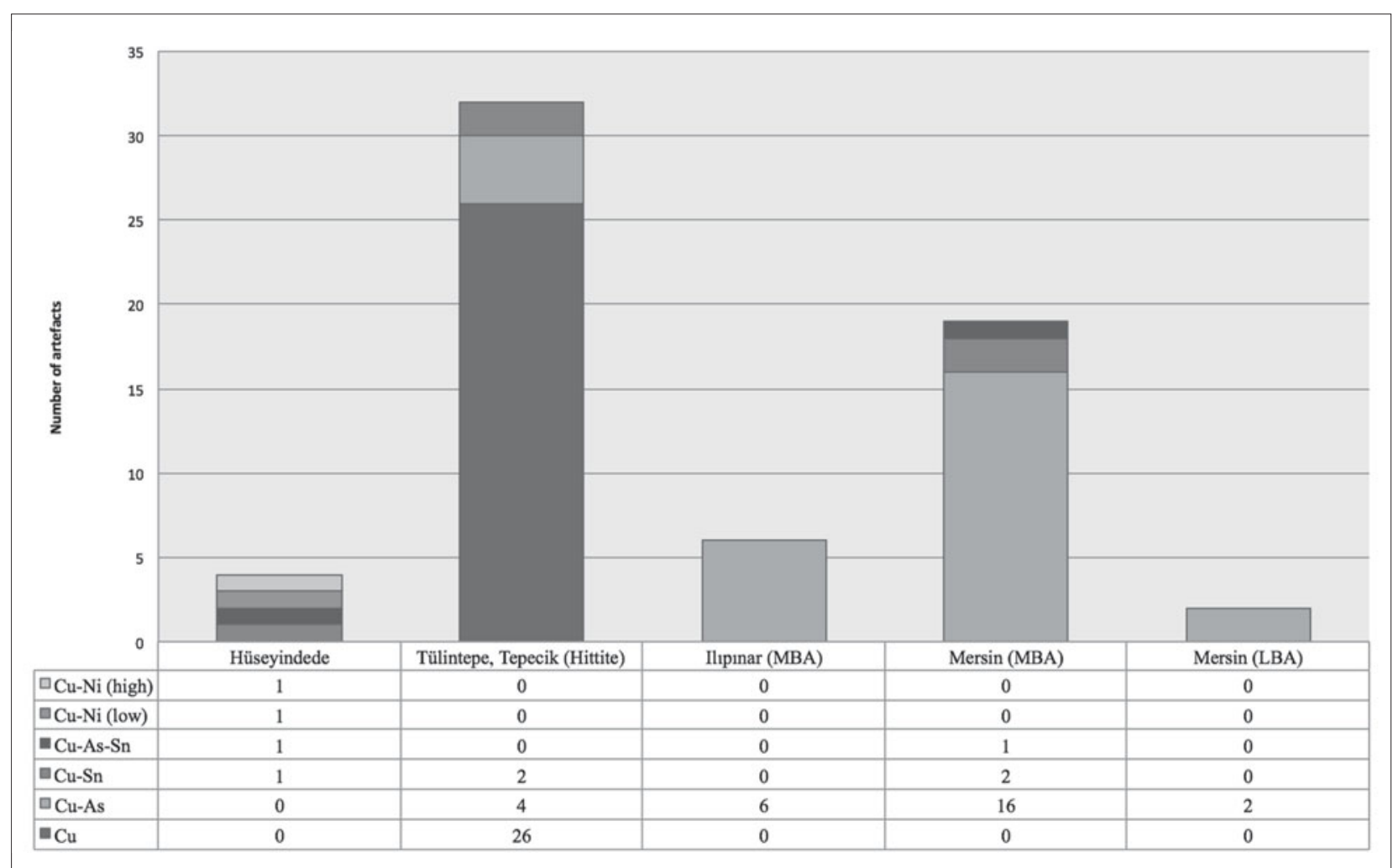

Fig 5. Comparative distributions of alloying practices at the sites discussed in the text (for Tülintepe, Tepecik, see Çukur, Kunç 1989; for Illpınar, see Begemann et al. 1994; for Mersin, see Gale et al. 1985). 
The existence of such alloys is linked to complex metallurgical practices, frequent recycling or the use of multiple sources (Lehner, Schachner 2017). However, due to the limitations of metallographic analysis, the lack of further inter- and intra-regional scientific data, as well as the absence of further artefacts, this cannot be considered a definitive conclusion. The shaft part of the nail can also be classified as a ternary alloy, despite the extremely high tin content at one analysis point. With regards to the head of the nail, however, the still-visible silvery colour may be due to the deliberate use of high-tin bronze to obtain a silvery sheen, as noticeably represented by the votive nail with a silver-coated head from Maşat Höyük. Using high levels of tin in order to alter the surface colour was not unknown in Hittite metallurgy. The surface analysis of the aforementioned treaty tablet revealed a composition of 31.64$37.83 \mathrm{wt} \%$ tin, which has been linked to the political and ritual significance of the artefact (Zimmermann et al. 2010).

The more intriguing alloy type identified at Hüseyindede is cupronickel alloy, with low- and highnickel variations. With high concentrations of nickel, the colour of copper changes to reveal a more silvery shine (figs 6,7) and the alloy becomes more ductile and hardens easily upon cold working (Lehner forthcoming). Variations in nickel levels show that cupronickel technology has existed since the Old Hittite period, at least to some extent. Distributions of the low- and high-nickel cupronickel artefacts found at sites discussed in this study are presented in figure 8. The Hüseyindede pins demonstrate low-nickel and high-nickel cupronickel variations. Their close parallels at Boğazköy have so far been determined to be high-nickel cupronickel (fig. 7; Lehner 2015: 165, 167, fig. 5:10, 12). Such variations in alloying element contents for similar pins dated to the Old Hittite to Empire period might be an indication of experimentation with the new alloy.

With reference to the existence of cupronickel alloys at sites like Boğazköy, Kastamonu-Kınık and KamanKalehöyük, the identification of cupronickel alloys at Hüseyindede plays a significant role in the development of the history of metallurgy. The existence of low- and high-nickel cupronickel at the site certainly links the presence of cupronickel alloys to an earlier stage in the history of the Hittites, namely to the Old Hittite or Old Kingdom period.

Even though low-nickel cupronickel was commonly used in the Near East as early as the fourth millennium BC at unprovenanced Sumerian sites (Cheng, Schwitter 1957: 353, table 2) and for the objects of the Nahal Mishmar hoard (Pernicka 1990; Tadmor et al. 1995; Hauptmann, Pernicka 2004), there is no reason to propose that development of this technology was imported to central Anatolia from the Levant or Mesopotamia two millennia later (Lehner 2015: 163). Diverse alloys produced by the

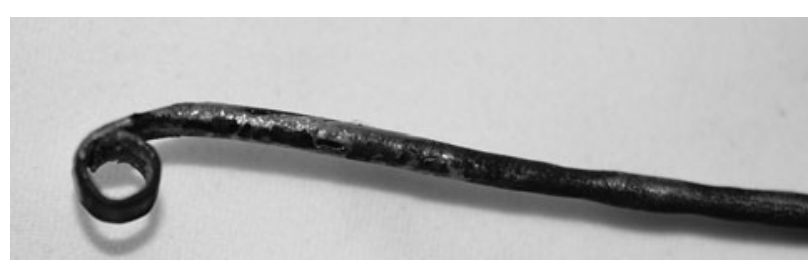

Fig 6. Detail of the silvery colour of the pin 7019.

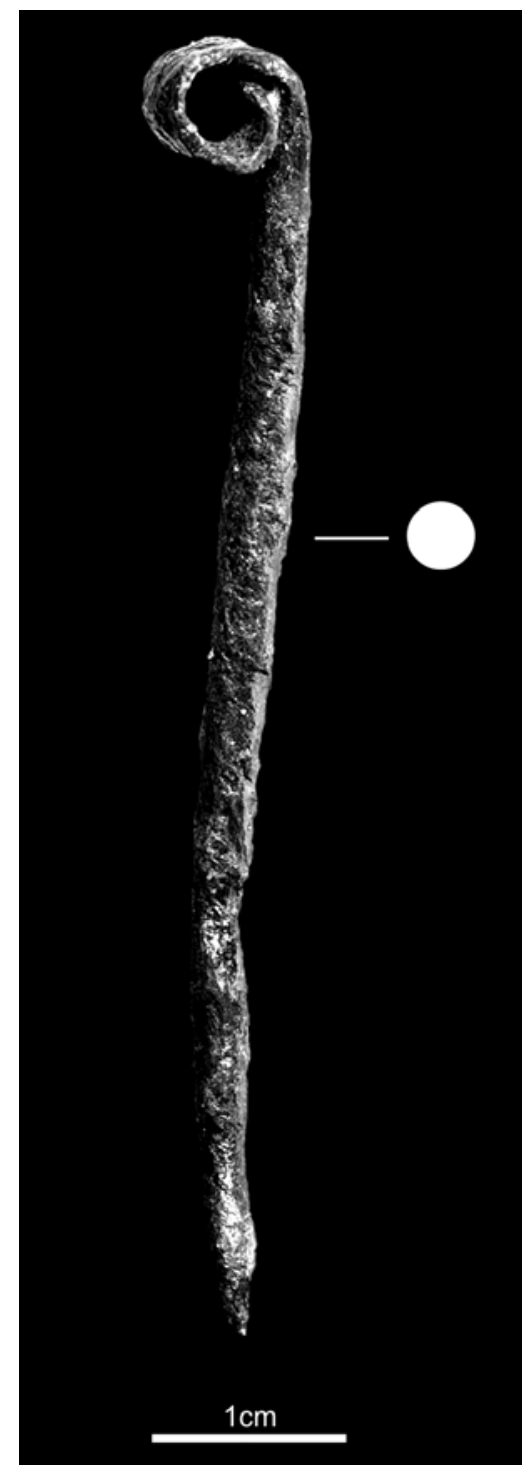

Fig 7. Cupronickel pin (Bo 09/972) from Boğazköy (photo courtesy of the Archive of the Bogazköy Expedition, Deutsches Archäologisches Institut, Joseph Lehner).

smelting of polymetallic ores, or mixed smelting, are also to be found in Anatolia, as evidenced by the copperarsenic-nickel alloys of late fourth-millennium BC Malatya Arslantepe, with nickel values as high as $9 \mathrm{wt} \%$ and with an outstanding nickel-arsenic correlation (Caneva, Palmieri 1983; Hauptmann et al. 2002). An Early Bronze Age copper ring fragment $(96.0 \mathrm{wt} \%$ copper) from 
Tülintepe (T.71-107) yielded a composition of $1 \mathrm{wt} \%$ nickel and 0.2wt\% cobalt (Çukur, Kunç 1989: 115, table 3), and a dagger (KK71-71) from the Early Bronze Age cemetery of Kalınkaya-Toptaştepe was found to contain $3.2 \mathrm{wt} \%$ nickel and 1.6wt\% arsenic (Geniş, Zimmermann 2014: 286, table 1, fig. 5:2). Thus, the use of copper-nickel alloys could well be the result of independent development, initiated by craftspeople exploiting and experimenting with local resources.

Though none has been investigated from an archaeological perspective, several nickel-bearing copper mineralisations in Anatolia, which may have been utilised for cupronickel technology, have been documented. Thus, it is impossible at this stage of research to assign the metal(s) of the Hüseyindede cupronickel pins to any particular source, but the amount of iron in the pins and the proximity of Sivas to Sungurlu (ca $450 \mathrm{~km}$ ) compared to Bitlis (ca $950 \mathrm{~km}$ ) places Divriği at a more advantageous position among the currently known potential local sources. Furthermore, the Hüseyindede low-cupronickel pin (7019) shows a composition of approximately $1 \mathrm{wt} \%$ arsenic, pointing to the issue of the use of nickel-arsenic minerals such as rammelsbergeite $\left(\mathrm{NiAs}_{2}\right)$ or niccolite (NiAs); the latter can be sourced from the Kurtbeyaz district of Güneş, Divriği. The availability of arsenic outcrops and copper ores in the Zara and Bulucan provinces of Sivas (Ryan
1960) should also be mentioned here. Arsenic deposits (orpiment and realgar) have also been documented at Durağan, east of Kastamonu (Özbal et al. 2000). It goes without saying that any nickel or nickel-bearing copper sources around Kastamonu and Tosya require further research from an archaeological perspective, regardless of the economic values of the metallic sources. The region could have been a supplier of copper-nickel ores as raw material (fig. 1) and/or the final cupronickel alloy products found at Hüseyindede, in addition to supplying sites like Kastamonu-Kınık, Boğazköy and/or Kaman-Kalehöyük.

\section{Conclusions}

In explaining the complex process of the development and diversification of copper alloys, it would be misleading to arrive at the conclusion that one copper alloy was replaced by another. Developments in alloying traditions clearly must have furthered the existing technical skills and knowhow of metalworkers (Northover 1998: 113). Thus, progress in metallurgy must have been highly complex. New archaeological models for the production and distribution of metals centred around geological (the locations of metallic resources, fuel and trade routes) and anthropogenic (labour, technical craft skills and the organisation of production) factors open new avenues towards an understanding of the dynamic social and technological

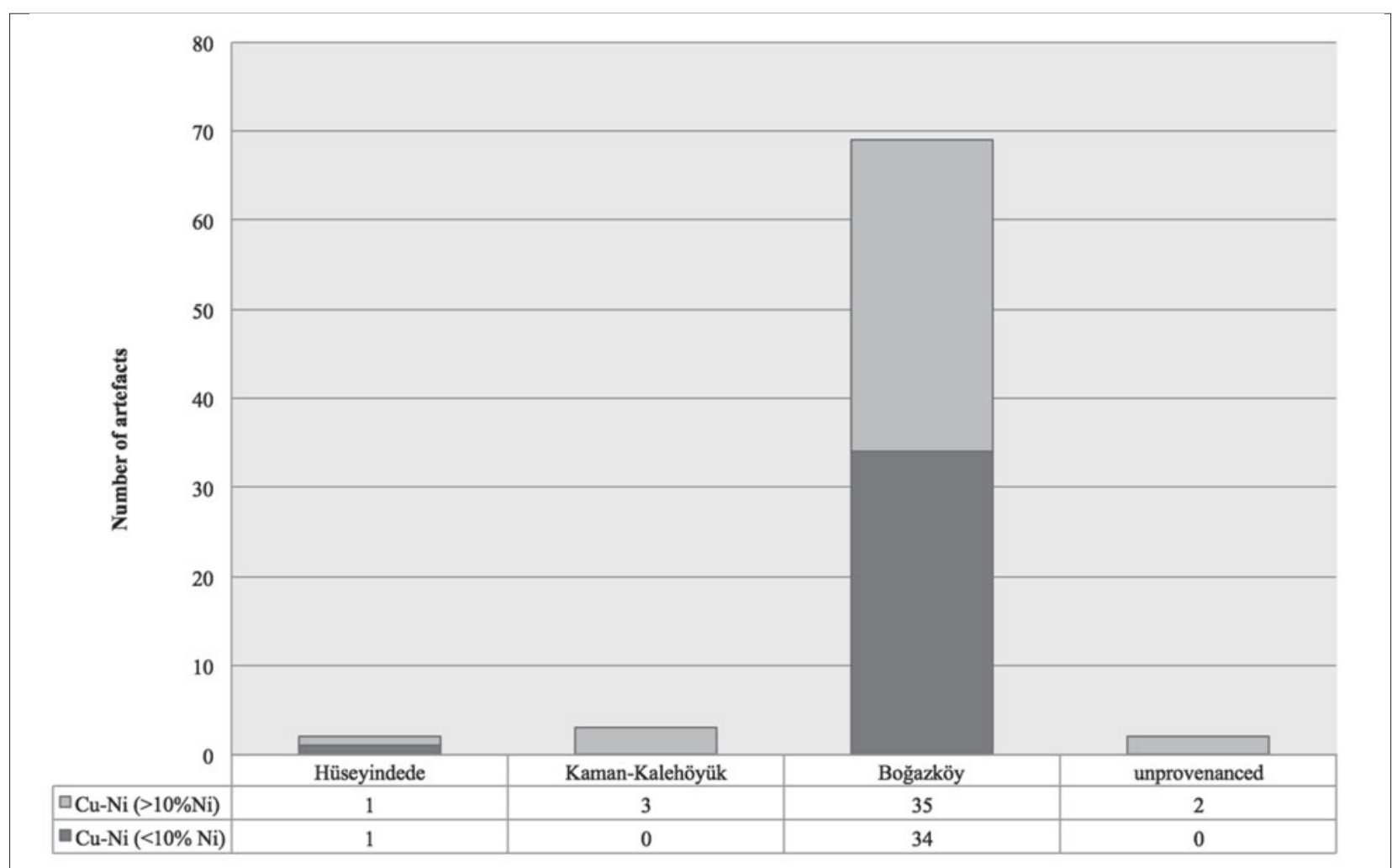

Fig 8. Comparative distributions of low-and high-cupronickel artefacts at sites discussed in the text (for KamanKalehöyük, see Hirao, Enomoto 1997; for Boğazköy, see Lehner 2014; 2015; for unprovenanced, see Northover 1998; Ipek, İbis forthcoming; Lehner forthcoming). 
relations behind ancient metallurgy (Erb-Satullo et al. 2017: 109). With its small but divergent metal assemblage, Hüseyindede now presents a noteworthy example of these developments. The information revealed through analysis of the metal artefacts, indicates the knowledge and skills of their creators.

Hüseyindede reflects a rural settlement model with local features. Nevertheless, the varied range of alloy types found at Hüseyindede reflects access to a range of different materials, likely deriving from various regions, even before the Hittites flourished as an imperial power. The degree of state management and control over economic activities such as metal production and distribution, as well as the trade of both raw materials and final products, have long been debated (Sherratt, Sherratt 1991; Liverani 2003; Routledge, McGeough 2009; Erb-Satullo et al. 2017; Frangipane 2017). Even though evidence of metallurgical practices in the Old Kingdom period is limited, written records and archaeometric research confirm that, during the Empire period, the Hittites controlled metal production, circulation and exchange as part of their imperial strategy (Lehner, Schachner 2017). Before the relatively strong control of resources during the Empire period, resource management in the Old Hittite period might, in fact, have been independent of state institutions. Local chiefs or high-ranking elites may have placed pressure on the local population and/or administration to search for and exploit new metals, which might have later led to the development of advanced metallurgical skills and thus the emergence of specialised metalworking and socioeconomic changes (Gale et al. 1985: 143). It is also possible that mobile communities with specialised skills in metallurgy and ore procurement may have been managed or controlled to a certain degree by centralised authorities (Frangipane 2017).

Highland settlements, as epitomised by Hüseyindede, could have benefitted from the exploitation of local resources and improved upon the traditional Hatti practice of metallurgy, in addition to belonging to already established trade networks. Considering the variation in composition of the metal artefacts in such a small sample set, as well as the fact that no evidence for a metal workshop has been found at the site, the possibility that the metal artefacts may have been transported to the temple through various networks should be considered. Unfortunately, neither any written documents nor any relevant archaeological materials (i.e. imported ceramics or metal ingots in the temple depot which would allow for further study of the possible involvement of the temple in a trade network or the existence of a temple-coordinated network) were recovered during the excavations. With the exception of the highly cultic nature of the relief vases, the rural and local character of the architecture and material assemblage of the site generally points to the existence of a selfsustaining settlement involved more plausibly in intraregional, rather than inter-regional, trade. The material concordance, in terms of both small finds and architectural remains, with İnandıktepe, Alaca Höyük (IIIa-b) and Boğazköy supports the likelihood of such intra-regional relations. The proximity of these sites to Hüseyindede and the existence of a route from Budaközü to Delice, extending as far as İnandıktepe through the Terme valley, also support the existence of such relations.

The discovery of bronze or ternary alloys at Hüseyindede demonstrates the continuation of technological knowledge and practices in the region from the Early Bronze Age and Assyrian Trading Colonies period. Some practices date back to the second half of the third millennium $\mathrm{BC}$, when the use of arsenical copper and bronze, along with numerous exotic alloy types, was amplified (Lehner et al. 2015 with references). Trade routes must have played a noteworthy role in the continuity of metallurgical traditions. Routes linking Hüseyindede to rich copper, arsenic and antimony sources in the northern section of central Anatolia, along the inner Black Sea coast (including the Çankırı, Amasya, Merzifon, Tokat and Sivas areas), could very well have played a role in the presence of diverse alloy types; such routes could also have played a part in the trade and exchange of various other goods, including finished objects.

The wealth of metal accumulation in the Halys basin from the Early Bronze Age raises questions regarding the possible locales of metal production, which, up to now, have not been identified with any degree of confidence. As far as raw materials (including, but not limited to, metal sources and fuel) are concerned, any informed discussion cannot go beyond unsupported assumptions. Likewise, little is understood about the spatial and social organisation of production in central-northern Anatolia during the third and second millennia BC. As clearly argued several decades ago, the replacement of speculations with facts regarding metallurgy requires further archaeometric and isotopic research on ores and ancient mining activities (Gales et al. 1985: 152). However, explorations focusing on the resources of the Halys basin are still in their infancy (Yalçın, İpek 2016 with references) and require further attention from scholars. Recent research in the southern Caucasus has successfully combined spatial data and chemical data, collected through survey, excavation and pXRF analysis, in order to assess the scale and complexity of the organisation of metal production (Erb-Satullo et al. 2017). Following a similar methodology, new surveys in the Delice valley (Çorum), specifically targeting questions related to ancient mining and raw-material procurements in the region, will hopefully contribute to our knowledge and understanding of the subject (Arıkan, Y1ldırım 2018). 
In addition to the continuation of the dominant alloys of the Bronze Age, the presence of new alloys, such as cupronickel, confirms that metalsmiths practised with new raw materials, as well as new metallurgical technologies. If resource management during the Old Hittite period was either fully or at least to a certain extent independent, then Hüseyindede is a clear case site demonstrating the exploitation and use of local resources, as well as experimentation with new raw materials. Certainly, there is not sufficient evidence to suggest that these objects were made on site, thereby demonstrating the use of local resources, but the alloy types do noticeably demonstrate the existence of a range of materials, accessed either directly or through trade.

Even though the reason behind the use of cupronickels is not clear at this stage of study, the silvery appearance of the cupronickel artefacts may suggest that it was used to mimic silver or high-tin bronze. Cupronickel alloy is also more rigid than silver, which makes it appropriate for use in artefacts like the chains of the treaty tablet, which weighs approximately $5 \mathrm{~kg}$. Due to their colour, ritually and religiously loaded artefacts, like the Boğazköy lunula pendant or the bullhorns and rhytons found at Kastamonu-Kınık, also point to the use of this alloy for prestigious items. The suggested archaeological context of the Hüseyindede pins - a temple area - supports this hypothesis.

In conclusion, the Hüseyindede metal artefacts represent a rare corpus dating to the Old Hittite period. Despite the limited number of artefacts, the analytical results fill a gap in our knowledge of the nature and significance of metallurgy in the history of the Hittites - as well as posing new questions.

\section{Acknowledgements}

We wish to thank the Director of Çorum Museum, Önder İpek, as well as specialists Resul İbiş, Banu Çilingir, Tuğba Ergül and Özge Eren. The Archaeology Laboratory of the Archaeology and History of Art Department at the Koç University generously provided the $\mathrm{pXRF}$ instrument. We are grateful for its support. We also extend our sincere gratitude to Joseph W. Lehner for sharing his work prior to publication and to Andreas Schachner for providing the image of the Boğazköy cupronickel pin. Gonca Dardeniz is indebted to the American Research Institute in Turkey for the M.J. Mellink fellowship awarded in support of her research.

\section{Bibliography}

Alkım, B.U., Alkım, H., Bilgi, Ö. 2003: İkiztepe II: Üçüncü, Dördüncü, Beşinci, Altıncı, Yedinci Dönem Kazılari (19761980). Ankara, Türk Tarih Kurumu Basımevi

Arıkan, B., Y1ldırım, T. 2018: 'Paleoclimate, geology, geomorphology, and Middle Holocene settlement systems in the Delice valley of north-central Anatolia' Journal of Field Archaeology 43.8: 570-90. https://doi.org/10.1080/00934690.2018.1535161

Ayaroğlu, H. 1980: ‘Tosya Kuzeybatısı'nın (Karadere) jeolojisi ve ekonomik olanakları’ Jeoloji Mühendisliği Ocak: 65-72

Bachmann, H.-G. 1984: 'Düsenrohre und Gebläsetöpfe: Keramikfunde aus metallverarbeitungs-Werkstätten' in K. Bittel, H.-G. Bachmann, R. Naumann, G. Neumann, P. Neve, W. Orthmann, H. Otten (eds), Boğazköy IV: Funde aus den Grabungen bis 1979. Berlin, Mann: 107-15

Begemann, F., Pernicka, E., Schmitt-Strecker, S. 1994: 'Metal finds from Ilıpınar and the advent of arsenical copper' Anatolica 20: 203-19

Bilgen, A.N. 1999: 'Kastamonu-Kınık kazısı 1994-1995 metalürjik buluntuları' Anadolu Araştırmaları 15: 269-93

Boehmer, R.M. 1972: Boğazköy-Hattuša: die Kleinfunde von Boğazköy aus den Grabungskampagnen 1931-1939 und 1952-1969. Berlin, Mann

Çağatay, M.N. 1987: ‘The Pancarlı nickel-copper sulfide mineralization, eastern Turkey’ Mineralium Deposita 22: 16371. https://doi.org/10.1007/BF00206605

Caneva, I., Palmieri, A.M. 1983: 'Metalwork at Arslantepe in late Chalcolithic and Early Bronze I: the evidence from metal analyses' in M. Frangipane, A. Palmieri (eds), Perspectives on Proto-urbanization in Eastern Anatolia: Arslantepe (Malatya): An Interim Report on 1975-1983 Campaigns = Origini 12.2: 637-54

Cheng, C.F., Schwitter, C.M. 1957: 'Nickel in ancient bronzes' American Journal of Archaeology 61.4: 351-65. https://doi.org/10.2307/500603

Çınaroğlu, A. 1990-1991: ‘Kastamonu kökenli bir grup Hitit gümüş(?) eseri’ Müze 4: 53-58

Çukur, A., Kunç, Ş. 1989: 'Analyses of Tepecik and Tülintepe metal artifacts' Anatolian Studies 39: 113-20. https://doi.org/10.2307/3642817

Dardeniz, G. 2016: 'Cultic symbolism at the city gates: two metal foundation pegs from Tell Atchana, Alalakh (Turkey)' Adalya 19: 31-50

Dardeniz, G., Yıldırım, T. forthcoming: 'Resuloğlu (Çorum, Turkey) updated: preliminary results of pXRF analysis of 
metal artifacts from the Early Bronze Age cemetery’ in F. Kulakoğlu, C. Michel, G. Öztürk (eds), Subartu: Proceedings of the 3rd Kültepe International Meeting. Turnhout, Brepols

Emre, K., Çınaroğlu, A. 1993: 'A group of metal Hittite vessels from Kınık-Kastamonu' in M.J. Mellink, E. Porada, T. Özgüç (eds), Aspects of Art and Iconography: Anatolia and its Neighbors: Studies in Honor of Nimet Özgüç. Ankara, Türk Tarih Kurumu Yayınları: 675-713

Erb-Satullo, N.L., Gilmour, B.J.J., Khakhutaishvili, N. 2017: 'Copper production landscapes of the south Caucasus' Journal of Anthropological Archaeology 47: 109-26. https://doi.org/10.1016/j.jaa.2017.03.003

Erkanal, H. 1977: Die Äxte und Beile des 2. Jahrtausends in Zentralanatolien. Munich, C.H. Beck

Frahm, E., Doonan, R. 2013: 'The technological versus methodological revolution of portable XRF in archaeology' Journal of Archaeological Science 40.2: 1425-34. https://doi.org/10.1016/j.jas.2012.10.013

Frangipane, M. 2017: 'The role of metal procurement in the wide interregional connections of Arslantepe during the late 4th - early 3rd millennia BC' in Ç. Maner, M.T. Horowitz, A.S. Gilbert (eds), Overturning Certainties in Near Eastern Archaeology: A Festschrift in Honor of K. Asllhan Yener. Boston/Leiden, Brill: $186-210$. https://doi.org/10.1163/9789004353572_014

Gale, N.H., Stos-Gale, Z.A., Gilmore, G.R. 1985: 'Alloy types and copper sources of Anatolian copper alloy artefacts' Anatolian Studies 35: 143-73. https://doi.org/10.2307/3642880

Genç, E. 2008: 'Kastamonu-Kınık kazıları ve yerleşimin çevre kültür bölgeleri ile ilişkileri' in D. Çelik, E. Genç (eds), Aykut Çınaroğlu'na Armağan/Studies in Honor of Aykut Çınaroğlu. Istanbul, Ege Yayınları: 105-33

Geniş, E., Zimmermann, T. 2014: 'Early Bronze Age metalwork in central Anatolia: an archaeometrical view from the hamlet' Praehistorische Zeitschrift 89.2: 280-90

Harada, K., Tagawa, Y., Nagashima, K., Nakao, K., Tsukahara, N. 1971: 'Pentlandite, niccolite and gersdorffite from the Han Deresi and Güneş districts, near Divrigi, Sivas, eastern Turkey’ Mineralogical Journal 6: $313-22$. https://doi.org/10.2465/minerj1953.6.313

Hauptmann, A., Schmitt-Strecker, S., Begemann, F., Palmieri, A. 2002: 'Chemical composition and lead isotopy of metal objects from the "Royal" tomb and other related finds at Arslantepe, eastern Anatolia' Paléorient 28.2: 43-69. https://doi.org/10.3406/paleo.2002.4745

Hauptmann, H., Pernicka, E. (eds) 2004: Die Metallindustrie in Mesopotamien von den Anfängen bis zum 2. Jahrtausend v. Chr. Rahden, M. Leidorf

Hawkins, D. 1993: 'A bowl epigraph of the official Taprammi’ in M.J. Mellink, E. Porada, T. Özgüç (eds), Aspects of Art and Iconography: Anatolia and its Neighbors: Studies in Honor of Nimet Özgüç. Ankara, Türk Tarih Kurumu Yayınları: 715-17

Hirano, H., Boyali, I. 1980: 'Geology of the nickel-copper deposits in the Pancarli area (Bitlis massif, eastern Turkey)' Unpublished Maden Etüd Report 1746. Ankara, MTA Institute (in Turkish)

Hirao, Y., Enomoto, J. 1997: 'Chemical analysis of copper objects excavated from 8th and 9th excavations of KamanKalehoyuk' Anatolian Archaeological Studies 6: 187-221

İpek, Ö., İbiş, R. forthcoming: ‘A unique Hittite bracelet from Çitli village of Çorum province’ in A. Öztan (ed.), Ŭgur Silistreli Armă̆an Kitabı. Ankara, Ankara University Press

Koşay, H.Z. 1934: 'Türkiye Cumhuriyeti Maarif Vekaletince yaptırılan Ahlatlıbel hafriyatı' Türk Tarih, Arkeologya ve Etnografya Dergisi 2: 3-100

Koşay, H.Z., Akok, M. 1966: Türk Tarih Kurumu Tarafından Yapılan Alaca Höyük Kazısı 1940-1948'deki Çalışmalara ve Keşiflere Ait Ilk Rapor. Ankara, Türk Tarih Kurumu Yayınları

Lechtman, H. 1981: 'Copper-arsenic bronzes from the north coast of Peru' in A-M. Cantwell, J.B. Griffin, N.A. Rothschild (eds), The Research Potential of Anthropological Museum Collections. New York, New York Academy of Sciences: $77-121$

- 1996: 'Dirty copper or chosen alloy? A view from the Americas' Journal of Field Archaeology 23.4: 477-514

Lehner, J.W. 2012: ‘A preliminary report on the microstructure and microanalysis of metal from Boğazköy' in A. Schachner (ed.), Die Ausgrabungen in Bogăzköy-Hattuša 2010 = Archäologischer Anzeiger 2011.1: 57-64

— 2014: 'A report on the archaeometallurgical research at Boğazköy' in A. Schachner (ed.), Die Ausgrabungen in Bogăzköy-Hattuša 2013 = Archäologischer Anzeiger 2014.1: 129-37

- 2015: Cooperation, the Craft Economy, and Metal Technology During the Bronze and Iron Ages in Central Anatolia. $\mathrm{PhD}$ thesis, University of California, Los Angeles

— forthcoming:'PXRF analysis of a Hittite bracelet at Çorum Museum’ in A. Öztan (ed.), Uğur Silistreli Armăgan Kitabı. Ankara, Ankara University Press 
Lehner, J.W., Schachner, A. 2017:'The organization of metal production at Hattuša: a first assessment' in Ç. Maner, M.T. Horowitz, A.S. Gilbert (eds), Overturning Certainties in Near Eastern Archaeology: A Festschrift in Honor of K. Aslihan Yener. Boston/Leiden, Brill: 403-35. https://doi.org/10.1163/9789004353572_023

Lehner, J.W., Yazgan, E., Pernicka, E., Kulakoğlu, F. 2015: 'Continuity of tin bronze consumption during the late 3rd millennium BC at Kültepe’ in F. Kulakoğlu, C. Michel (eds), Proceedings of the 1st Kültepe International Meeting, Kültepe 19-23 September 2013: Studies Dedicated to Kutlu Emre. Turnhout, Brepols: 195-217

Liverani, M. 2003: 'The influence of political institutions on trade in the ancient Near East (Late Bronze to Early Iron Age)' in C. Zaccagnini (ed.), Mercanti e politica nel mondo antico. Rome, L'Erma di Bretschneider: 119-37

Massa, M., McIlfatrick, O., Fidan, E. 2017: 'Patterns of metal procurement, manufacture and exchange in Early Bronze Age northwestern Anatolia: Demircihüyük and beyond' Anatolian Studies 67: 51-83. https://doi.org/10.1017/S0066154617000084

Matsumura, K. 2008: 'The Early Iron Age in Kaman-Kalehöyük: the search for its roots' in D. Bonatz, R.M. Czichon, F.J. Krepper (eds), Fundstellen gesammelte Schriften zur Archäologie und Geschichte Altvorderasiens ad honorem Hartmut Kühne. Wiesbaden, Harrassowitz: 41-50

Meeks, N.D. 1986: 'Tin-rich surfaces on bronze: some experimental and archaeological considerations' Archaeometry 28.2: 133-62. https://doi.org/10.1111/j.1475-4754.1986.tb00383.x

Meyer, R.J. 1967: Gmelins Handbuch der Anorganischen Chemie 8. Auflage: Nickel Teil AI. Berlin/Heidelberg, Springer

Mielke, D.P. 2006: 'İnandıktepe und Sarissa: ein Beitrag zur Datierung althethitischer Fundkomplexe' in D.P. Mielke, U.D. Schoop, J. Seeher (eds), Strukturierung und Datierung in der hethitischen Archäologie. Istanbul, Ege Yayınları: 251-76

Muhly, J.D. 1985: 'Beyond typology: Aegean metallurgy in its historical context' in N.C. Wilkie, D.E. Coulson (eds), Contributions to Aegean Archaeology. Minneapolis, University of Minnesota: 109-41

Müller-Karpe, A. 1994: Altanatolisches Metallhandwerk. Neumünster, Wachholtz

Northover, J.P. 1998: 'Exotic alloys in antiquity' in T. Rehren, A. Hauptmann, J.D. Muhly (eds), Metallurgica Antiqua. Bochum, Deutschen Bergbau-Museum: 113-21

Otten, H. 1988: Die Bronzetafel aus Boğazköy: ein Staatsvertrag Tuthalijas IV. Wiesbaden, Harrassowitz

Özbal, H., Pehlivan N., Earl, B. 2000: 'Durağan ve Bakır Çay arsenik cevherleşmelerinin jeolojik, mineralojik ve kimyasal incelenmesi’ Arkeometri Sonuçları Toplantısı 16: 29-40

Özgüç, T. 1988: Inandıktepe: Eski Hitit Çă̆l'nda Önemli Bir Kült Merkezi/An Important Cult Center During the Hittite Period. Ankara, Türk Tarih Kurumu Yayınları

— 1994: 'A votive foundation-nail in the temple of Maşathöyük' in M. Dietrich, O. Loretz (eds), Beschrieben und Deuten in der Archaeologie des alten Orients: Festschrift für Ruth Mayer-Opificius. Münster, Ugarit Verlag: 227 34

Pernicka, E. 1990: 'Gewinnung und Vorbreitung der Metalle in prähistorischer Zeit: achte Theodor Mommsen-Vorlesung' Jahrbuch des Römisch-Germanisches Zentralmuseum 37: 21-129

Pilz, R. 1937: 'Kastamonu ve Sinop vilayetlerindeki çeşitli mineral yataklarının tetkiki’ Unpublished Maden Etüd Report. Ankara, MTA Institute

Routledge, B., McGeough, K. 2009: 'Just what collapsed? A network perspective on "palatial" and "private" trade at Ugarit' in C. Bachhuber, R.G. Roberts (eds), Forces of Transformation: The End of the Bronze Age in the Mediterranean. Oxford, Oxbow: 22-29

Ryan, C.W. 1960: A Guide to the Known Minerals of Turkey. Ankara, MTA Publications

Schachner, A. 2009: 'Die Ausgrabungen in Boğazköy-Hattuša 2008' Archäologischer Anzeiger 2009: 21-72

Sherratt, A., Sherratt, S. 1991: 'From luxuries to commodities: the nature of Mediterranean Bronze Age trading systems' in N.H. Gale (ed.), Bronze Age Trade in the Mediterranean: Papers Presented at the Conference Held at Rewley House, Oxford in December 1989. Uppsala, Paul Åstroms Forlag: 351-86

Siegelová, J., Tsumoto, H. 2011: 'Metals and metallurgy in Hittite Anatolia' in H. Genz, D.P. Mielke (eds), Insights into Hittite History and Archaeology. Leuven/Paris/Walpole MA, Peeters: 275-300

Sipahi, T. 2000: 'Eine althethitische Reliefvase von Hüseyindede Tepesi' Istanbuler Mitteilungen 50: 63-85

— 2003: ‘2002 yılı Hüseyindede kazısı’ Kazı Sonuçları Toplantısı 25.2: 179-86

Sipahi, T., Yıldırım, T., Ediz, İ. 2000: ‘1998 yılı Yörüklü/Hüseyindede kazısı' Kazı Sonuçları Toplantısı 21: 349-52

Tadmor, M., Kedem, D., Begemann, F., Hauptmann, A., Pernicka, E., Schmitt-Strecker, S. 1995: ‘The Nahal Mishmar hoard from the Judean desert: technology, composition, and provenance' Atiqot 27: 95-148

Temizer, R. 1954: 'Kayapınar hüyüğü buluntuları' Belleten 18: 317-30 
Tylecote, R.F. 1979: 'The effect of soil conditions on the long-term corrosion of buried tin-bronzes and copper' Journal of Archaeological Science 6.4: 345-68. https://doi.org/10.1016/0305-4403(79)90018-9

Tylecote, R.F., Ghaznavi, H.A., Boydell, P.J. 1977: 'Partitioning of trace elements between ores, fluxes, slags and metal during the smelting of copper' Journal of Archaeological Science 4: 305-33. https://doi.org/10.1016/03054403(77)90027-9

von der Osten, H.N. 1937: The Alishar Hüyük: Seasons of 1930-32 2. Chicago, Chicago University Press

Wilhelm, G. 2005: 'Zur Datierung der älteren Landschenkungsurkunden' Altorientalische Forschungen 32: 272-79. https://doi.org/10.1524/aofo.2005.32.2.272

Yalçın, Ü., İpek, Ö. (eds) 2016: Prähistorische Kupfergewinnung in Derekutuğun, Anatolien I: Montanarchäologische Forschungen in den Jahren 2009-2011: ein Vorbericht. Bochum, Deutschen Bergbau-Museum

Yıldırım, T. 2000: 'Yörüklü/Hüseyindede: eine neue hethitische Siedlung im südwesten von Çorum' Istanbuller Mitteilungen 50: 41-60

- 2001: 'Hüseyindede kabartmalı vazosundan betimlenen dans eden bir Hititli' Ankara Üniversitesi Dil ve Tarih Coğrafya Fakültesi Dergisi 41.1: 1-7. https://doi.org/10.1501/Dtcfder_0000000216

— 2002: 'Hüseyindede Tepesi’nde bulunan ikinci kabartmalı vazoya ait yeni bir müzisyen’ Ankara Üniversitesi Dil ve Tarih Coğrafya Fakültesi Dergisi 42.1/2: 1-7. https://doi.org/10.1501/Dtcfder_0000000201

- 2009: 'Hüseyindede: a settlement in north-central Anatolia: contributions to Old Hittite art' in F.P. Daddi, G. Torri, C. Corti (eds), Central-North Anatolia in the Hittite Period. Rome, Herder: 235-46

— 2013a: 'Hüseyindede' in M. Doğan-Alparslan, M. Alparslan (eds), Hititler: Bir Anadolu Imparatorluğu/Hittites: An Anatolian Empire. Istanbul, Yapı Kredi Yayınları: 228-37

— 2013b: 'Hüseyindede kazısı ve Eski Hitit sanatına katkıları' Çorum Kültür Sanat: Bilim, Kültür, Sanat, Tarih ve Turizm Dergisi: Hitit Söyleşileri II, Özel Sayı 14: 78-82

Yıldırım, T., Sipahi, T. 1999: ‘1997 yılı Çorum bölgesi yüzey araştırmaları’ Araştırma Sonuçları Toplantısı 26.1: 433-37

— 2001:'Yörüklü/Hüseyindede kazıs1 1999: mimari ve küçük buluntular’ Müze Yıllı̆̆ 2000: 312-41

— 2002: '2001 yılı Yörüklü/Hüseyindede Tepesi kazısı' Kazı Sonuçları Toplantısı 24.2: 259-66

Zimmermann, T., Özen, L., Kalayc1, Y., Akdoğan, R. 2010: 'The metal tablet from Boğazköy-Hattuša: first archaeometric impressions' Journal of Near Eastern Studies 69.2: 225-29. https://doi.org/10.1086/597762

Zimmermann, T., Yıldırım, T. 2008: 'Three best to have in plenty: rethinking central Anatolian Early Bronze Age alloying traditions' in Ü. Yalçın, H. Özbal, A.G. Paşamehmetoğluu (eds), Ancient Mining in Turkey and the Eastern Mediterranean. Ankara, Atılım University Publications: 87-97 